Resources

Conservation \&

Recycling

\title{
Pyrolysis of oil sludge with additives of sodium and potassium compounds
}

\author{
Je-Lueng Shie ${ }^{\mathrm{a}}$, Jyh-Ping Lin ${ }^{\mathrm{b}}$, Ching-Yuan Chang ${ }^{\mathrm{a}, *}$, \\ Duu-Jong Lee ${ }^{\mathrm{c}}$, Chao-Hsiung $\mathrm{Wu}^{\mathrm{d}}$ \\ a Graduate Institute of Environmental Engineering, National Taiwan University, Taipei 106, Taiwan, ROC \\ ${ }^{\mathrm{b}}$ Department of Environmental Engineering, Lan-Yang Institute of Technology, Tou-Cheng, I-Lan 261, \\ Taiwan, ROC \\ ${ }^{\mathrm{c}}$ Department of Chemical Engineering, National Taiwan University, Taipei 106, Taiwan, ROC \\ d Department of Environmental Engineering, Da-Yeh University, Changhua 515, Taiwan, ROC
}

Accepted 9 July 2002

\begin{abstract}
Previous efforts were made to convert the oil sludge into useful resources such as lower molecule organic compounds and carbonaceous residues by pyrolysis with the carrier gas of $\mathrm{N}_{2}$. In the present study, the oil sludge from the oil storage tank of a typical petroleum refinery plant located in the northern Taiwan was used as the raw material of pyrolysis. The influences of using sodium and potassium compounds as additives on the possible improvement of the pyrolysis of oil sludge are investigated. The additives employed include two groups: (1) sodium compounds $\left(\mathrm{NaOH}, \mathrm{NaCl}\right.$ and $\left.\mathrm{Na}_{2} \mathrm{CO}_{3}\right)$, and (2) potassium compounds $(\mathrm{KCl}, \mathrm{KOH}$ and $\mathrm{K}_{2} \mathrm{CO}_{3}$ ). For the increases of conversion, the additives provide the offers in the order of $\mathrm{K}_{2} \mathrm{CO}_{3}>\mathrm{KOH}>\mathrm{NaOH}>\mathrm{Na}_{2} \mathrm{CO}_{3}>\mathrm{KCl}>\mathrm{NaCl}>$ no additives. It appears that the above additives enhance the reaction rates when the temperatures are in $650-710 \mathrm{~K}$, following the orders $\mathrm{NaOH}>\mathrm{Na}_{2} \mathrm{CO}_{3}>\mathrm{NaCl}>$ no additives, and $\mathrm{K}_{2} \mathrm{CO}_{3}>\mathrm{KOH}>\mathrm{KCl}>$ no additives. The additives achieve the improvement of the quality of pyrolysis oil (as sum of light and heavy naphtha and light gas oil) in the order of $\mathrm{KOH}>\mathrm{KCl}>\mathrm{K}_{2} \mathrm{CO}_{3}>\mathrm{NaOH}>\mathrm{Na}_{2} \mathrm{CO}_{3}>$ $\mathrm{NaCl}>$ no additives. Nevertheless, the additives improve the liquid yields in the order of $\mathrm{KCl}>\mathrm{Na}_{2} \mathrm{CO}_{3}>\mathrm{NaCl}>$ no additives $>\mathrm{NaOH}>\mathrm{K}_{2} \mathrm{CO}_{3}>\mathrm{KOH}$. All this information is useful not only to the improvement of a pyrolysis system but also to the better utilization of liquid oil products.
\end{abstract}

(C) 2002 Published by Elsevier B.V.

\footnotetext{
* Corresponding author. Tel./fax: +886-2-2363-8994

E-mail address: cychang3@ccms.ntu.edu (C.-Y. Chang).
} 
Keywords: Pyrolysis; Oil sludge; Sodium compounds

\section{Introduction}

For both economic and environmental reasons, the transformation of wastes such as waste oil (Sanjay et al., 1994), petroleum vacuum residues (Hajdu et al., 1996; Joo et al., 1999; Mochida et al., 1990), oil sludge (Ayen and Swanstorm, 1992; Chang et al., 2000; Shie et al., 2000), spent plastics (Lin et al., 1996; Maksimova and Krivoruchko, 1999; Shie et al., 2002a; Wu et al., 1993) and biomass (Samolada et al., 2000; Shihadeh and Hochgerb, 2000) to effective energy sources has became important recently. Energy recycling into fuel oils is attractive and has been commercially tested and operated. Among the crude oil refining processes, a lot of oil sludge accumulates from petroleum refineries. Oil sludge is the main solid waste of a petroleum refinery and contains a large amount of combustibles with high heating values. Therefore, oil sludge is a useful recycling resource and the conversion of oil sludge into fuels also has been recognized as an attractive approach.

In the previous study, the one, two- and three-reaction models were proposed to predict the pyrolysis experimental results of oil sludge (Shie et al., 2000). Extensive study has been conducted on the analyses of major products obtained from the pyrolysis of oil sludge in a separate paper (Chang et al., 2000). The distillation characteristics of liquid product from the pyrolysis of oil sludge is close to diesel oil. However, it contains a significant amount of vacuum residues of about $9.57 \mathrm{wt} . \%$. This affects the quality of pyrolysis oil and its use. Treatment of wastes by catalytic cracking has some advantages over thermal degradation (noncatalytic method). Addition of a useful catalyst or additive in the catalytic cracking process at adequate reaction conditions has a great potential to shorten the cracking time, lower the required temperature, increase the cracking ability of wastes, reduce the proportion of solid residue, and/or narrow the product distribution (Chiu and Cheng, 1999; Maksimova and Krivoruchko, 1999). Coprocess of coal with petroleum wastes that contained dispersant additives can improve the dispersion of the coal particles and the catalysts during liquefaction (Hajdu et al., 1996). For the improvement of pyrolysis oil, upgrading the pyrolysis oil or adding catalysts or additives in oil sludge to advance the pyrolysis reactions is necessary. In a previous study (Shie et al., 2002b), the catalytic degradations of oil sludge in the presence of inexpensive and non-harmful additives of (1) aluminum compounds $\left(\mathrm{Al}, \mathrm{Al}_{2} \mathrm{O}_{3}\right.$ and $\left.\mathrm{AlCl}_{3}\right)$; and (2) iron compounds $\left(\mathrm{Fe}, \mathrm{Fe}_{2} \mathrm{O}_{3}, \mathrm{FeSO}_{4} \cdot 7 \mathrm{H}_{2} \mathrm{O}, \mathrm{FeCl}_{3}\right.$ and $\left.\mathrm{Fe}_{2}\left(\mathrm{SO}_{4}\right)_{3} \cdot n \mathrm{H}_{2} \mathrm{O}\right)$ have been studied in detail. For the above additives tested, the most active additive with greatest conversion is $\mathrm{Fe}_{2}\left(\mathrm{SO}_{4}\right)_{3} \cdot n \mathrm{H}_{2} \mathrm{O}$. The additives of $\mathrm{Fe}_{2} \mathrm{O}_{3}$ and $\mathrm{Fe}_{2}\left(\mathrm{SO}_{4}\right)_{3}$. $n \mathrm{H}_{2} \mathrm{O}$ can improve the liquid qualities ( $q$, in terms of sum of light and heavy naphtha and light gas oil) of pyrolysis oils (Shie et al., 2002b).

The present research interest has been directed toward the use of sodium and potassium compounds as catalysts/additives. The catalytic degradations of oil sludge in the presence of (1) sodium compounds $\left(\mathrm{NaOH}, \mathrm{NaCl}\right.$ and $\left.\mathrm{Na}_{2} \mathrm{CO}_{3}\right)$; and (2) potassium compounds $\left(\mathrm{KCl}, \mathrm{KOH}\right.$ and $\left.\mathrm{K}_{2} \mathrm{CO}_{3}\right)$ are studied in detail. The catalytic 
Table 1

Elemental analysis of oil sludge and solid residues of pyrolysis oil without and with additives in this study $(\mathrm{g}-\mathrm{h})$

\begin{tabular}{|c|c|c|c|c|c|c|c|c|c|}
\hline & \multicolumn{2}{|l|}{$\mathrm{C}$} & \multicolumn{2}{|l|}{$\mathrm{H}$} & \multicolumn{2}{|l|}{$\mathrm{N}$} & \multicolumn{2}{|l|}{$\mathrm{C} / \mathrm{H}$} & \multirow[t]{2}{*}{ Mass ratio } \\
\hline & $\mathrm{a}$ & $\mathrm{b}$ & $\mathrm{a}$ & $\mathrm{b}$ & $\mathrm{a}$ & $\mathrm{b}$ & c & & \\
\hline Initial dry oil sludge & $83.9(0.90)^{\mathrm{a}}$ & & $12.0(0.58)$ & & $0.81(0.53)$ & 6.99 & 100 & & \\
\hline Without additives & $64.39(0.6)$ & & $2.59(0.06)$ & & $1(0.04)$ & & 24.86 & $16.34^{\mathrm{b}}$ & $16.34^{\mathrm{c}}$ \\
\hline With $\mathrm{NaOH}$ & $28.18(3.35)$ & $45.92(0.71)$ & $2.95(0.52)$ & 4.81 & $0.4(0.1)$ & 0.65 & 9.55 & 17.95 & 12.39 \\
\hline With $\mathrm{NaCl}$ & $24.23(0.4)$ & $42.72(0.66)$ & $0.89(0.13)$ & 1.57 & $0.39(0.02)$ & 0.69 & 27.21 & 20.61 & 12.58 \\
\hline With $\mathrm{Na}_{2} \mathrm{CO}_{3}$ & $35.95(0.25)$ & $63.64(0.99)$ & $1.14(0.13)$ & 2.02 & $0.49(0.02)$ & 0.87 & 31.5 & 21.04 & 12.98 \\
\hline With $\mathrm{KCl}$ & $31.65(3.44)$ & $54.6(0.85)$ & $1.82(0.09)$ & 3.13 & $0.51(0.07)$ & 0.88 & 17.44 & 22.28 & 11.75 \\
\hline With KOH & $33.52(0.33)$ & $52.62(0.82)$ & $2.04(0.28)$ & 3.2 & $0.37(0.18)$ & 0.58 & 16.44 & 20.87 & 13.34 \\
\hline With $\mathrm{K}_{2} \mathrm{CO}_{3}$ & $26.97(0.41)$ & $51.28(0.79)$ & $1.84(0.13)$ & 3.5 & $0.37(0)$ & 0.7 & 14.65 & 21.56 & 11.48 \\
\hline
\end{tabular}

a, Based on mass of residues (including additives), units in wt. \% for $\mathrm{C}, \mathrm{H}, \mathrm{N} ; \mathrm{b}$, based on mass of oil sludge residues (with deduction of additives), units in wt. $\%$ for $\mathrm{C}, \mathrm{H}, \mathrm{N}$; c, in wt./wt. for $\mathrm{C} / \mathrm{H}$ ratio (b column); g, $\mathrm{HR}=5.2 \mathrm{~K} / \mathrm{min}$; h, final temperature $=740 \mathrm{~K}$.

${ }^{a}$ Numbers in parentheses are standard deviations $\left(\sigma_{n-1}\right)$.

${ }^{\mathrm{b}}$ Mass ratio of residues (including additives) to sum of initial dry oil sludge and initial additives added, $M^{\prime}$.

${ }^{c}$ Mass ratio of oil sludge residues (with deduction of additives) to initial dry oil sludge, $M$. 
degradation is performed by the use of a dynamic thermogravimetric (TG) reaction system at the temperature-programmed heating rate $(\mathrm{HR})$ of $5.2 \mathrm{~K} / \mathrm{min}$ in nitrogen atmosphere of the range of $378-740 \mathrm{~K}$.

\section{Experimental}

\subsection{Materials}

The oil sludge used in this study was sampled from the crude oil storage tank of a typical petroleum refinery plant located in the northern Taiwan. Nitrogen gas for the purge gas, with $99.99 \%$ purity, is purchased from the Ching-Feng-Harng Co. Ltd. in Taipei, Taiwan. The oil sludge sample is dried in a recycle ventilation drier for $24 \mathrm{~h}$ at $378 \mathrm{~K}$ before use.

\subsection{Experimental procedure}

\subsubsection{Thermogravimetry ( $T G$ )}

The lab-scale apparatus and experimental procedures for the pyrolysis of oil sludge are the same as the previous study (Chang et al., 2000; Lin et al., 1996; Shie et al., 2000; Shihadeh and Hochgerb, 2000; Wu et al., 1993). The HR employed for the pyrolysis of oil sludge without and with additives was $5.2 \mathrm{~K} / \mathrm{min}$. The dried sample was placed on a quartz disk that was enclosed in quartz shell and tube reactor with purging nitrogen gas for $2 \mathrm{~h}$ at $378 \mathrm{~K}$ for further drying to a constant mass prior to starting the temperature rise under a specific HR. A sample of known mass (1000 mg of oil sludge or $1000 \mathrm{mg}$ of oil sludge with $100 \mathrm{mg}$ of additives) was used, and the flow rate was adjusted to the desired value, say $50 \mathrm{~cm}^{3} / \mathrm{min}$ under $101.3 \mathrm{kPa}(1 \mathrm{~atm})$ and $293 \mathrm{~K}$. The effluent gas was cold-trapped at $298 \mathrm{~K}$ and then vented to a fume hood. When the run was finished, the nitrogen gas was kept flowing till the temperature of the system is below $373 \mathrm{~K}$.

Two duplicate experimental runs were performed in order to obtain representative conversion and reaction rate data. For illustration, the standard deviations $\left(\sigma_{n-1}\right)$ of the residual mass fractions for the pyrolysis of oil sludge without and with the additive of $\mathrm{K}_{2} \mathrm{CO}_{3}$ were about $0.001-0.018$ and $0.001-0.025$, respectively. Ten duplicate experimental runs were performed in order to collect sufficient amounts of solid residues and liquid oils for analysis. Two or more than three trials for product analysis are conducted. The errors are reflected by the expressions of relative errors or standard deviations, for examples, as illustrated in Table 1.

\subsubsection{Sampling}

The mass of oil sludge used for the experiments on the pyrolysis products was 1000 or $1000 \mathrm{mg}$ with $100 \mathrm{mg}$ of additives. The products of pyrolysis of oil sludge without or with additives were divided into solid residues, liquid oils (condensable liquid, 298 $\mathrm{K})$, and noncondensable gases $(298 \mathrm{~K})$ which were vented to a fume hood. The program-rising temperature for collecting solid residues was set to stop at $740 \mathrm{~K}$. The 
condensates collected in $378-740 \mathrm{~K}$ were the liquid oils. The connecting glass line between the pyrolysis furnace and condensing tube was wrapped with a thermal belt at $410 \mathrm{~K}$.

\subsubsection{Analysis}

A Hewlett-Packard (HP 5890 series II) gas chromatograph (GC) with an injector port and a flame ionization detector (FID) was used for the quantitative analyses of liquid oils. The chromatographic column was a Supelco fused silica capillary column (SPB-5, $30 \mathrm{~m}, 0.53 \mathrm{~mm}$ i.d., $1.5 \mu \mathrm{m}$ film thickness). An integrator from HewlettPackard (HP 3395) was connected to the GC for graphing and integrating purposes. The operating conditions for the simulation distillation of liquid products and commercial oils were set as follows: injector temperature $393 \mathrm{~K}$, detector temperature $473 \mathrm{~K}$, column temperature following the sampling injection being held at $313 \mathrm{~K}$ for $1 \mathrm{~min}$, programmed to $573 \mathrm{~K}$ at $10 \mathrm{~K} / \mathrm{min}$, and finally held at $573 \mathrm{~K}$ for $20 \mathrm{~min}$, nitrogen carrier gas flow rate $3.5 \mathrm{ml} / \mathrm{min}$, nitrogen make-up gas $26 \mathrm{ml} /$ min, sample volume $0.1 \mu 1$.

The elemental analyses for the solid residues were made on a Perkin-Elmer, Norwalk, CT2400 elemental analyzer with 0.3 wt.\% accuracy, i.e. C, H and N analyzed with Heraeus CHN-O-RAPID, and $\mathrm{S}, \mathrm{Cl}$ analyzed with Tacussel Coulomax 78 automatic coulometric titrator.

\subsubsection{Chemicals}

The principal liquid standards for establishing calibration curve were the same as the previous study (Chang et al., 2000). The liquid standards for the elemental analyzer were sufonilic acid, 1-chloro-2,4-dinitrobenzene, 3,5-dinitrobenzoic acid, acetanilide, benzoic acid and stearic acid. Fifteen chemicals were used as additives and directly added (physically mixed) into the quartz disk with oil sludge. They included two groups: (1) sodium compounds $\left(\mathrm{NaOH}, \mathrm{NaCl}\right.$ and $\mathrm{Na}_{2} \mathrm{CO}_{3}$ ), and (2) potassium compounds $\left(\mathrm{KCl}, \mathrm{KOH}\right.$ and $\left.\mathrm{K}_{2} \mathrm{CO}_{3}\right)$. All of the compounds are commercially available and directly used without further purification.

Quantitative analysis of liquid products was based on the calculation using the linear calibration response equations of standards. The equation was generated for each of the liquid standards using a minimum of five different concentrations with three replicates at each concentration. All correlation coefficients $\left(r^{2}\right)$ of linear calibration response curves were greater than 0.996 .

\section{Results and discussion}

\subsection{Thermal degradation of additives}

In the sole pyrolysis of oil sludge, the residual mass fraction of oil sludge $(M)$ decreases as the thermal pyrolysis temperature $(T)$ increases (Shie et al., 2000). With the addition of additive into the oil sludge, the mass residual fraction of additive $\left(M_{\mathrm{a}}\right)$ may decrease along with that of oil sludge during pyrolysis. To clarify the 


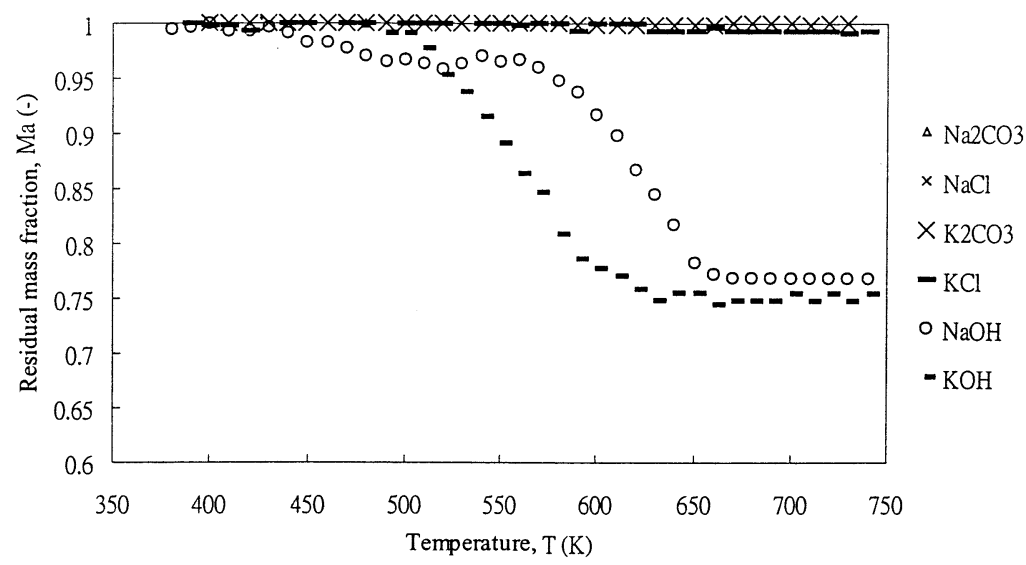

Fig. 1. Residual mass fraction $\left(M_{\mathrm{a}}\right)$ curves of additives used in this study at $5.2 \mathrm{~K} / \mathrm{min}$ heating rate.

actual mass loss of oil sludge only, a variation of residual mass fractions of $M$ and $M_{\mathrm{a}}$ must be examined and compared. The residual mass fraction of $M_{\mathrm{a}}$ is expressed as

$$
M_{\mathrm{a}}=\frac{m_{\mathrm{a}}}{m_{\mathrm{a} 0}}
$$

where $m_{\mathrm{a}}$ is present mass of additive at $T, m_{\mathrm{a} 0}$ is initial mass of additive.

The residual mass fraction of sole additive $\left(M_{\mathrm{a}}\right)$ in thermal degradation at HR of $5.2 \mathrm{~K} / \mathrm{min}$ are shown in Fig. 1. Under the thermal degradation temperature range of $378-740 \mathrm{~K}$, the values of $M_{\mathrm{a}}$ of $\mathrm{NaCl}, \mathrm{KCl}, \mathrm{Na}_{2} \mathrm{CO}_{3}$ and $\mathrm{K}_{2} \mathrm{CO}_{3}$ do not have obvious reductions; however, those of $\mathrm{NaOH}$ and $\mathrm{KOH}$ decrease as $T$ increases. The sample was dried in a recycle ventilation drier for $24 \mathrm{~h}$ at $378 \mathrm{~K}$ before use. Therefore, the water in the sample was negligible. The $M_{\mathrm{a}}$ of $\mathrm{NaOH}$ and $\mathrm{KOH}$ decrease starting at 470 and $520 \mathrm{~K}$, and almost constant after 640 and $650 \mathrm{~K}$, respectively. The acute descends of $M_{\mathrm{a}}$ are reasonable due to their low evaporating points (with boiling points (bps) of $591 \mathrm{~K}$ for $\mathrm{NaOH}$ and $678 \mathrm{~K}$ for $\mathrm{KOH}$ ).

\subsection{Effects of additives on conversion of pyrolysis of oil sludge}

The oil sludge used in this study is sampled from the crude oil storage tank of a typical petroleum refinery. Its high values of combustible (58.97 wt.\% of wet basis), heating value of dry basis $(10681 \mathrm{kcal} / \mathrm{kg})$, low heating value of wet basis $(5870 \mathrm{kcal} /$ $\mathrm{kg}$ ) and C element (83.94 wt.\% of dry basis) suggests that the waste of oil sludge would be a valuable resource (Shie et al., 2000). For the sole pyrolysis of oil sludge, the major gaseous products (noncondensable gases at $298 \mathrm{~K}$ ) are $\mathrm{CO}_{2}(50.88 \mathrm{wt} . \%)$, 


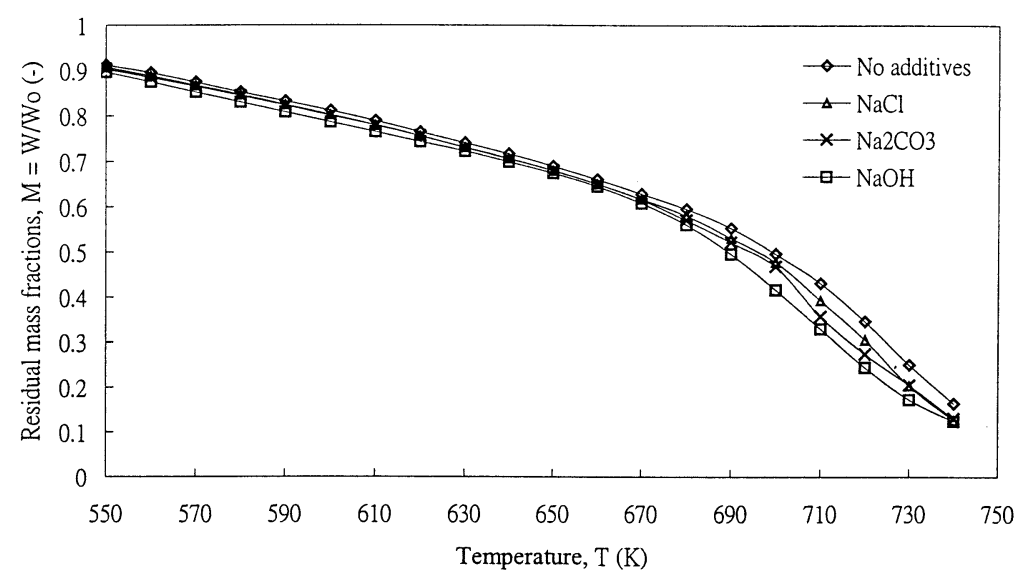

Fig. 2. Residual mass fractions $(M)$ for pyrolysis of oil sludge without and with sodium compound additives at $5.2 \mathrm{~K} / \mathrm{min}$ heating rate (with deduction of additives $M_{\mathrm{a}}$ ).

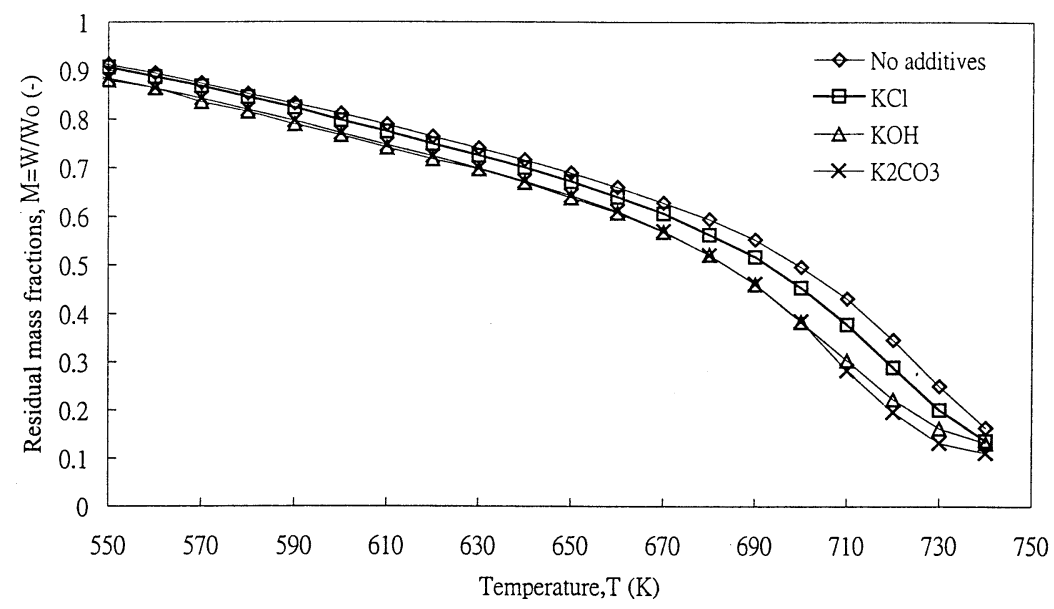

Fig. 3. Residual mass fractions $(M)$ for pyrolysis of oil sludge without and with potassium compound additives at $5.2 \mathrm{~K} / \mathrm{min}$ heating rate (with deduction of additives $M_{\mathrm{a}}$ ).

hydrocarbons (HCs, 25.23 wt.\%), $\mathrm{H}_{2} \mathrm{O}(17.78$ wt.\%) and $\mathrm{CO}$ (6.11 wt.\%; Chang et al., 2000). The HCs mainly consist of low molecular paraffins and olefins $(\mathrm{C} 1-\mathrm{C} 2$, $51.61 \mathrm{wt} . \%$ of HCs). The distillation characteristic of liquid product (condensate of gas at $298 \mathrm{~K}$ ) from the sole pyrolysis of oil sludge (collecting temperature range of $378-873 \mathrm{~K})$ is close to diesel oil. However, it contains a significant amount of vacuum residues of about 9.57 wt.\% (Chang et al., 2000). For the reduction of vacuum residues, which affect the qualities of liquid oils significantly, and lower the reaction temperature, the catalytic degradation of oil sludge in the presence of sodium and potassium compounds was studied. When the mass loss of additive is 


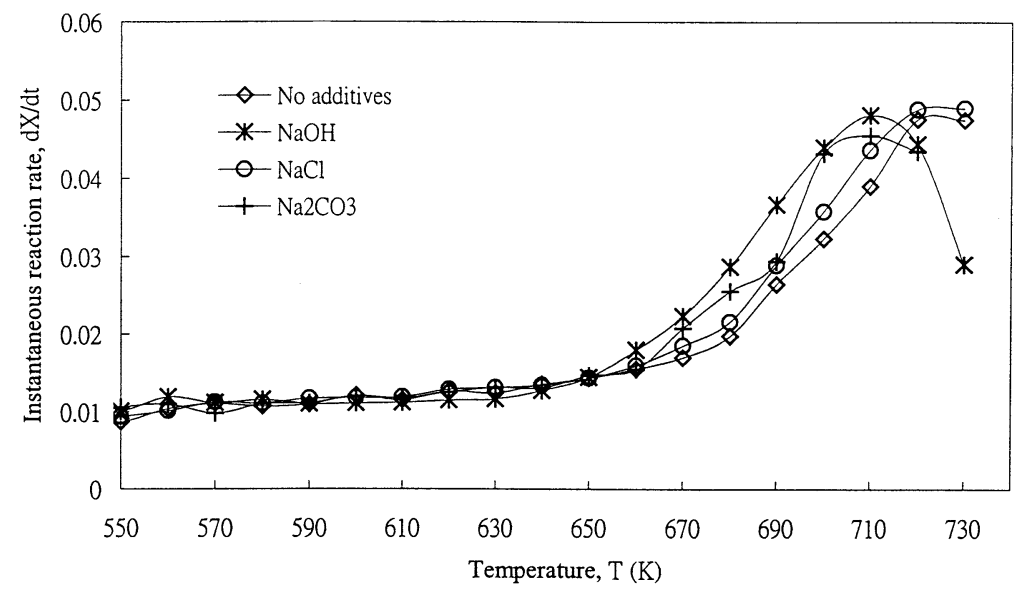

Fig. 4. Instantaneous reaction rate $(r=\mathrm{d} X / \mathrm{d} t)$ vs. temperature at $5.2 \mathrm{~K} / \mathrm{min}$ heating rate for pyrolysis of oil sludge without and with sodium compound additives (with deduction of additives).

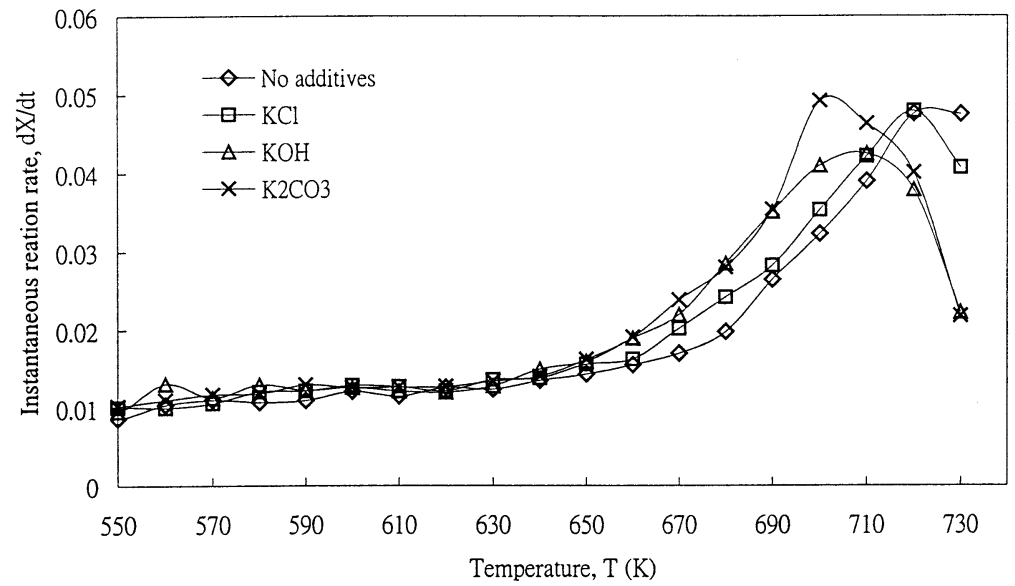

Fig. 5. Instantaneous reaction rate $(r=\mathrm{d} X / \mathrm{d} t)$ vs. temperature at $5.2 \mathrm{~K} / \mathrm{min}$ heating rate for pyrolysis of oil sludge without and with potassium compound additives (with deduction of additives).

considered, the residual mass fraction of oil sludge $(M)$ is expressed as

$$
M=\frac{W}{W_{0}}=1-X
$$

where $W=m-m_{\mathrm{a}}, W_{0}=m_{0}-m_{\mathrm{a} 0} ; X$ is conversion of oil sludge and $m, m_{\mathrm{a}}$ are present masses of sample and additive at $T(\mathrm{mg}) ; m_{0}, m_{\mathrm{a} 0}$ are initial masses of sample and additive (mg).

Figs. 2 and 3 illustrate the relation between $M$ and $T$ with deduction of additives $M_{\mathrm{a}}$, for the pyrolysis systems with and without sodium and potassium compounds, 


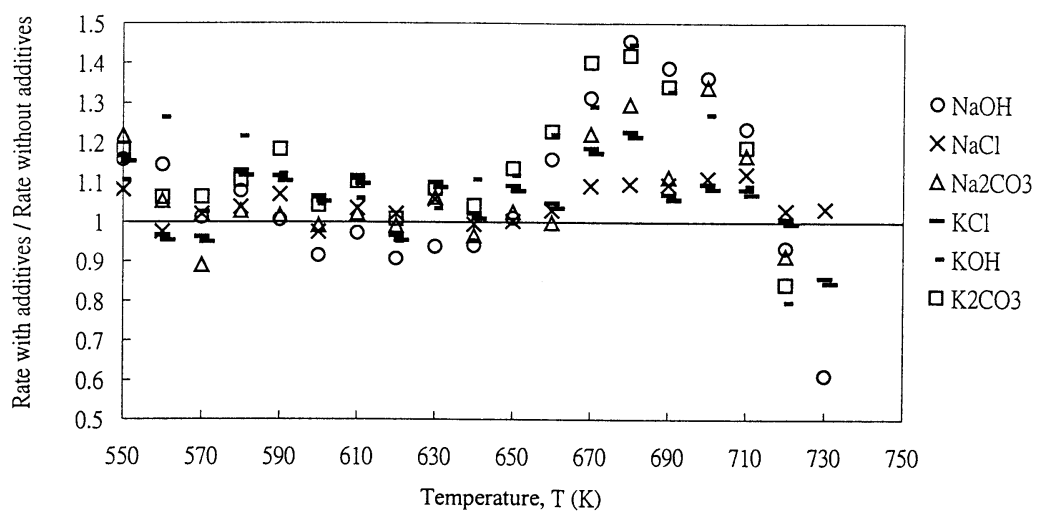

Fig. 6. Ratios of instantaneous reaction rates with to that without additives for pyrolysis of oil sludge at $5.2 \mathrm{~K} / \mathrm{min}$ heating rate (with deductions of additives).

respectively. It appears that all the values of $M$ in the presence of additives are lower than those in the absence of additives. Before $650 \mathrm{~K}$, the differences between absence and presence of additives were not obvious except that of $\mathrm{K}_{2} \mathrm{CO}_{3}$ and $\mathrm{KOH}$. In terms of conversion $X(=1-M)$, the enhancing effects of additives are in the order of $\mathrm{K}_{2} \mathrm{CO}_{3}>\mathrm{KOH}>\mathrm{NaOH}>\mathrm{Na}_{2} \mathrm{CO}_{3}>\mathrm{KCl}>\mathrm{NaCl}>$ no additives. After $650 \mathrm{~K}$, all the conversions with the presence of additives are higher than those without additives. This may be due to the dispersion phenomenon. Sanjay et al. (1994) pointed out that the dispersant additives present in the waste oil are believed to enhance coal conversion. Further, the results indicate that the degradation of oil sludge with additives can be carried out at a lower temperature to achieve the same degradation (conversion) than that without additives. In other words, it can, therefore, save the energy and treatment cost for the oil sludge pyrolysis.

\subsection{Effects of additives on reaction rates of pyrolysis of oil sludge}

The variations of instantaneous reaction rates $(r=\mathrm{d} X / \mathrm{d} t)$ in the presence and absence of additives with the deductions of additives in the pyrolysis of oil sludge are shown in Figs. 4 and 5 for $\mathrm{Na}$ and $\mathrm{K}$-compounds, respectively. Their ratios $\left(R_{\mathrm{pa}}\right.$ is the rate with additive/rate without additive) are also illustrated in Fig. 6. For $T<$ $650 \mathrm{~K}$, the values of instantaneous reaction rates with and without additives are lower than 0.017 per s (Figs. 4 and 5). In $650-710 \mathrm{~K}$, the additives enhance the reaction rates, following the orders $\mathrm{NaOH}>\mathrm{Na}_{2} \mathrm{CO}_{3}>\mathrm{NaCl}>$ no additives, and $\mathrm{K}_{2} \mathrm{CO}_{3}>\mathrm{KOH}>\mathrm{KCl}>$ no additives at $710 \mathrm{~K}$, with the values of $R_{\mathrm{pa}}$ of about $1.03-1.45$, respectively. However, above $720 \mathrm{~K}$, the rates without additives are predominant and larger, that is with $R_{\mathrm{pa}}<1$. The more active the additive is, the more tendency toward the lower temperature corresponding to the maximum value of reaction rate is. From these results, the favorable reaction temperature range with the presence of additives is $650-710 \mathrm{~K}$. 


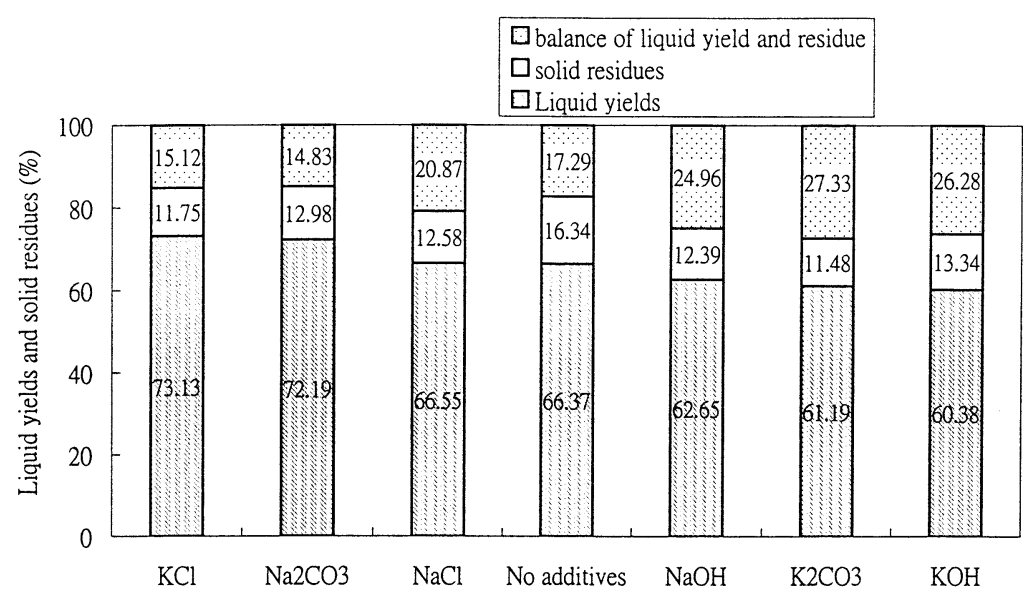

Fig. 7. Liquid yields and solid residues of pyrolysis of oil sludge without and with additives at $5.2 \mathrm{~K} / \mathrm{min}$ heating rate in $378-740 \mathrm{~K}$.

\subsection{Influences of additives on solid residues}

At the final pyrolysis temperature $\left(T_{\mathrm{f}} ; 740 \mathrm{~K}\right)$, the residual mass fractions of sample $\left(M^{\prime}\right)$ (without deducting corresponding masses of additives) and oil sludge $(M)$ are shown in Table 1 , where $M^{\prime}=W^{\prime} / W_{0}^{\prime}\left(W^{\prime}, \mathrm{W}_{0}^{\prime}\right.$ is present and initial masses of sample, respectively). Also included are the results of the elemental analysis of solid residues. At $740 \mathrm{~K}$, the lowest $M$ is that with the additive of $\mathrm{K}_{2} \mathrm{CO}_{3}$. Therefore, it is the most active additive in $378-740 \mathrm{~K}$. Meanwhile, it indicates that carbon (C) is the major element in solid residues. The variation of carbon element of solid residues with the additive of $\mathrm{Na}_{2} \mathrm{CO}_{3}$ relative to that without additives is not obvious. However, there are sharp reductions of carbon element for the cases with $\mathrm{NaCl}$, $\mathrm{NaOH}, \mathrm{K}_{2} \mathrm{CO}_{3}, \mathrm{KOH}$ and $\mathrm{KCl}$. It is noted that the $\mathrm{C} / \mathrm{H}$ values are lower for $\mathrm{NaOH}$ of $9.55, \mathrm{~K}_{2} \mathrm{CO}_{3}$ of $14.65, \mathrm{KOH}$ of $16.44, \mathrm{KCl}$ of 17.44 than that without additives of 24.86. This might be due to the higher reductions of carbon (C) with additives of $\mathrm{NaOH}, \mathrm{K}_{2} \mathrm{CO}_{3}, \mathrm{KOH}$ and $\mathrm{KCl}$. As for the higher $\mathrm{C}$ reduction of the additive of $\mathrm{NaCl}$ and also with higher $\mathrm{C} / \mathrm{H}$ value, this might be due to the higher reduction of hydrogen $(\mathrm{H})$ than that without additive.

\subsection{Influences of additives on yields and qualities of liquid oils}

The liquid oils were collected by passing the gaseous products through a glass connecting line wrapped with a heating tape of $410 \mathrm{~K}$ before collecting at $298 \mathrm{~K}$. They were mostly collected in the first condensing tube immersed in $298 \mathrm{~K}$ water bath. The liquid yields without and with additives are expressed as 
Table 2

Distillation characteristics of pyrolysis oil without and with additives in this study and some commercial oils

\begin{tabular}{lcclcc}
\hline & Light naphtha $343-366 \mathrm{~K}$ & Heavy naphtha $366-477 \mathrm{~K}$ & Light gas oil $477-616 \mathrm{~K}$ & Heavy gas oil $616-811 \mathrm{~K}$ & Vacuum residue $>811 \mathrm{~K}$ \\
\hline Without additives & $\sim 0$ & $7.45^{\mathrm{a}}$ & 43.9 & 48.3 & 0.34 \\
With $\mathrm{NaOH}$ & $\sim 0$ & 11.37 & 51.95 & 36.06 & 0.62 \\
With $\mathrm{NaCl}$ & $\sim 0$ & 7.64 & 49.8 & 42.35 & 0.21 \\
With $\mathrm{Na} \mathrm{CO}_{3}$ & $\sim 0$ & 9.48 & 50.9 & 39.43 & 0.18 \\
With $\mathrm{KCl}$ & 0.04 & 14.4 & 54.04 & 29.25 & 2.16 \\
With $\mathrm{KOH}$ & 0.58 & 17.16 & 57.26 & 24.75 & 0.25 \\
With $\mathrm{K}_{2} \mathrm{CO}_{3}$ & 0.38 & 12.53 & 55.37 & 31.67 & 0.05 \\
$\mathrm{GL}^{(3)}$ & 10.07 & 62.93 & 26.15 & 0.85 & $\sim 0$ \\
$\mathrm{DL}^{(3)}$ & 0.04 & 7.84 & 87.27 & 4.78 & 0.38 \\
$\mathrm{FL}^{(4)}$ & $\sim 0$ & 4.03 & 46.01 & 49.59 & 0.64 \\
$\mathrm{HL}^{(4)}$ & $\sim 0$ & 0.29 & 23.88 & 75.19 & \\
\hline
\end{tabular}

GL, DL, FL, HL: gasoline, diesel oil, fuel oil and heavy oil; pyrolysis temperature range $=378-740 \mathrm{~K}$; heating rate $(\mathrm{HR})=5.2 \mathrm{~K} / \mathrm{min}$

${ }^{\text {a }}$ Unit, in wt. $\%$. 


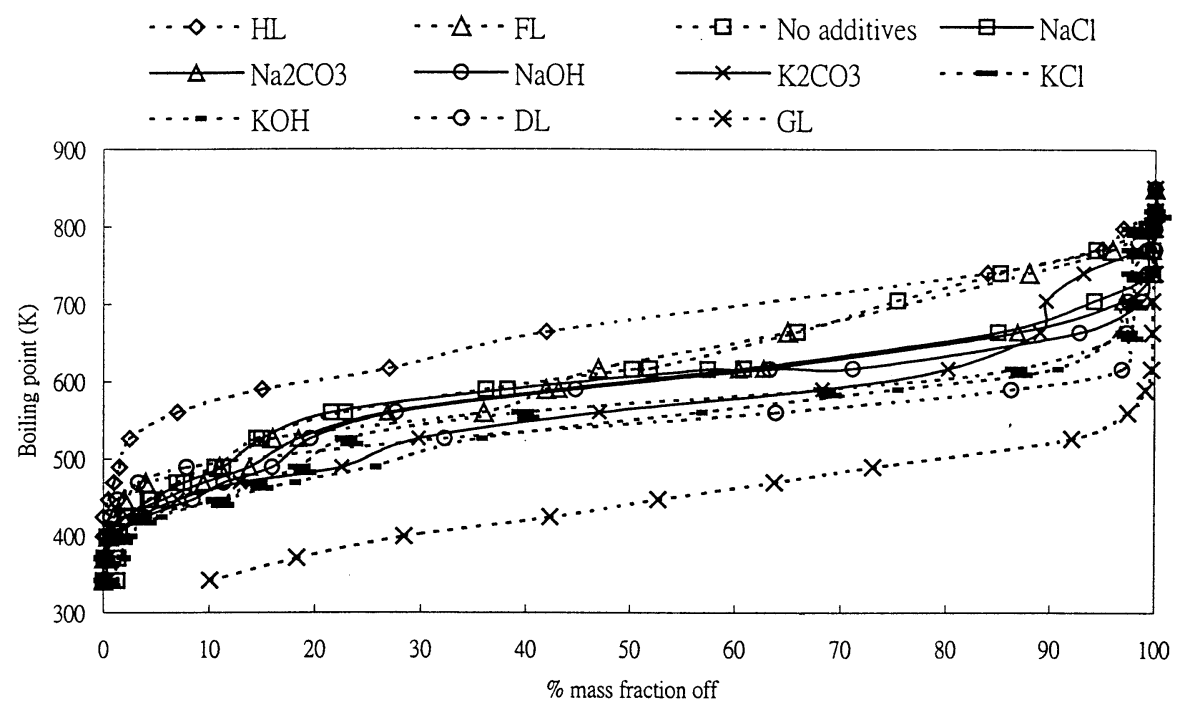

Fig. 8. Simulated distillation results of pyrolysis oil without and with additives and some commercial oils.

$Y$ (liquid yield, wt. $\%)=\frac{m_{\mathrm{L}}}{W_{0}}$

where $m_{\mathrm{L}}$ is total mass of collected liquids $(\mathrm{mg}), W_{0}=m_{0}-m_{\mathrm{a} 0}(\mathrm{mg})$, and $m_{0}, m_{\mathrm{a} 0}$ is initial masses of sample and additives, respectively $(\mathrm{mg})$.

The liquid yields and solid residues of the pyrolysis of oil sludge without and with additives in 378-740 $\mathrm{K}$ are shown in Fig. 7. From Fig. 7, the liquid yields are 73.13 and 72.19 wt. $\%$ with the addition of $\mathrm{KCl}$ and $\mathrm{Na}_{2} \mathrm{CO}_{3}$, respectively, which are higher than that without additives (66.37 wt.\%).

The liquid oils and commercial oils are analyzed for the different boiling points by GC, according to the Standard Test Method for Boiling Range Distribution of Petroleum Fractions, proposed by the ASTM D-2887 method (ASTM, 1984). Five portions of oils are cut apart as listed in Table 2. The simulated distillation results are shown in Fig. 8. From Table 2; Fig. 8, the liquid oil collected in $378-740 \mathrm{~K}$ for the pyrolysis of oil sludge without additive contains, in wt.\%, about 7.45 heavy naphtha, 43.9 light gas oil, 48.3 heavy gas oil and 0.34 vacuum residues, respectively. This is very close to fuel oil. Also from Table 2; Fig. 8, all additives improve the qualities (in terms of sum of light and heavy naphtha and light gas oil) of liquid oils. The additives achieve the improvement of the quality of pyrolysis oil in the order of $\mathrm{KOH}>\mathrm{KCl}>\mathrm{K}_{2} \mathrm{CO}_{3}>\mathrm{NaOH}>\mathrm{Na}_{2} \mathrm{CO}_{3}>\mathrm{NaCl}>$ no additives. The best quality of pyrolysis oil of $\mathrm{KOH}$ is between diesel oil and fuel oil. Nevertheless, the additives improve the liquid yields $(Y)$ in the order of $\mathrm{KCl}>\mathrm{Na}_{2} \mathrm{CO}_{3}>\mathrm{NaCl}>\mathrm{no}$ additives $>\mathrm{NaOH}>\mathrm{K}_{2} \mathrm{CO}_{3}>\mathrm{KOH}$. It is noted that some additives (such as $\mathrm{KOH}, \mathrm{K}_{2} \mathrm{CO}_{3}$ and $\mathrm{NaOH}$ ) with highly catalytic activities reduce the liquid yields and increase the qualities of the liquid oils except that of $\mathrm{KCl}$. 


\section{Conclusions}

The catalytic degradation is performed using a dynamic TG reaction system at the temperature-programmed $\mathrm{HR}$ of $5.2 \mathrm{~K} / \mathrm{min}$ in nitrogen atmosphere in $378-740 \mathrm{~K}$. The influences of using sodium and potassium compounds as additives on the pyrolysis of oil sludge are investigated in this study. The additives employed included two groups: (1) sodium compounds $\left(\mathrm{NaOH}, \mathrm{NaCl}\right.$ and $\left.\mathrm{Na}_{2} \mathrm{CO}_{3}\right)$; and (2) potassium compounds $\left(\mathrm{KCl}, \mathrm{KOH}\right.$ and $\left.\mathrm{K}_{2} \mathrm{CO}_{3}\right)$. For the above additives tested, the most active additive with greatest conversion was $\mathrm{K}_{2} \mathrm{CO}_{3}$. It appears that the above additives enhance the values of $r$ in $650-710 \mathrm{~K}$. The more active the additive is, the more tendency toward the lower temperature corresponding to the maximum value of reaction rate is. However, above $720 \mathrm{~K}$, the ratios of reaction rates in the presence to absence of additives $\left(R_{\mathrm{pa}}\right)$ are less than 1. All additives improve the qualities (in terms of sum of light and heavy naphtha and light gas oil) of liquid oils and the additive of $\mathrm{KOH}$ give the best quality of pyrolysis oil. Nevertheless, the additives of $\mathrm{KCl}$ and $\mathrm{Na}_{2} \mathrm{CO}_{3}$ give the greatest liquid yields. All this information is useful not only to the proper design of a pyrolysis system but also to the better utilization of liquid oil products.

\section{Acknowledgements}

We express our sincere thanks to the National Science Council of Taiwan for the financial support, under the contract number NSC89-2211-E-002-013.

\section{References}

ASTM D2887. Boiling range distribution of petroleum fraction by gas chromatography, 1984 .

Ayen RJ, Swanstrom CP.Low temperature thermal treatment of petroleum refinery waste sludgesEnviron. Prog., vol. 11(5).

Chang CY, Shie JL, Lin JP, Wu CH, Lee DJ, Chang CF.Major products obtained from the pyrolysis of oil sludgeEnergy Fuel, vol. 14.

Chiu SJ, Cheng WH. Thermal degradation and catalytic cracking of poly (ethylene terephthalate). Polym Degrad Stability 1999;63:407-12.

Hajdu PE, Tierney JW, Wender I. Effect of catalytic hydropretreatment of petroleum vacuum resid on coprocessing with coal. Energy Fuel 1996;10:493-503.

Joo HK, Hool JN, Curtis CW. Determination of effective conditions for two-stage coprocessing of coal with waste plastics and petroleum resid. Energy Fuels 1999;13:1128-34.

Lin JP, Chang CY, Wu CH, Shih SM. Thermal degradation kinetics of polybutadiene rubber. Polym Degrad Stability 1996;53:295-300.

Maksimova NI, Krivoruchko OP. Study of thermocatalytic decomposition of polyethylene and polyvinyl alcohol in the presence of an unsteady — state Fe - containing catalyst. Chem Eng Sci 1999;54:4351-7.

Mochida I, Zhao XZ, Sakanishi K. Supressing of sludge formation by two-stage hydrocracking of vacuum residue at high conversion. Ind Eng Chem Res 1990;29:2324-7.

Samolada MC, Papafotica A, Vasalos IA. Catalyst evaluation for catalytic biomass pyrolysis. Energy Fuels 2000;14:1161-7. 
Sanjay HG, Tarrer AR, Marks C. Iron-based catalysts for coal/waste oil coprocessing. Energy Fuels 1994;8:99-104.

Shie JL, Chang CY, Lin JP, Wu CH, Lee DJ. Resources recovery of oil sludge by pyrolysis: kinetics study. J Chem Technol Biotechnol 2000;75:1-8.

Shie JL, Chen YH, Chang CY, Lin JP, Lee DJ, Wu CH. Thermal pyrolysis of polyvinyl alcohol and its major products. Energy Fuels 2002;16(1):109-18.

Shie JL, Chang CY, Lin JP, Lee DJ, Wu CH. Use of inexpensive additives in pyrolysis of oil sludge. Energy Fuels 2002;16(1):102-8.

Shihadeh A, Hochgreb S. Diesel engine combustion of biomass pyrolysis oils. Energy Fuels 2000;14:260 74.

$\mathrm{Wu} \mathrm{CH}$, Chang $\mathrm{CY}$, Hor JL. On the thermal treatment of plastic mixtures of msw: pyrolysis kinetics. Waste Manage 1993;13:221-35. 